\title{
A Review of Nanostructured Ca-aluminate Based Biomaterials within Odontology and Orthopedics
}

\author{
Leif Hermansson ${ }^{\dagger}$ \\ Applied Research Sweden AB, Tönnes väg 7B, SE-26377 Mölle, Sweden \\ (Received December 19, 2017; Revised January 16, 2018; Accepted January 25, 2018)
}

\begin{abstract}
This presentation will give an overview of Ca-aluminate based biomaterials and their proposed use within the field of nanostructured biomaterials. The paper describes typical features of Ca-aluminate materials with regard to technology, chemistry, biocompatibility including hemocompatibility and bioactivity, and developed microstructure. Special focus will be on the developed microstructure, which is in the nanosize range. Application possibilities within odontology, orthopedics, and drug delivery are presented. The nanostructure including pore size below $5 \mathrm{~nm}$ in these structures opens up this material for some use in specific dental-related applications in which antibacterial and bacteriostatic aspects are of importance, and as thin coating on implants within dental and orthopaedic applications. Nanosize porosity is essential in drug delivery systems for controlled release of medicaments. The priority field for Ca-aluminate biomaterials is implant materials, which use minimally-invasive techniques to offer in vivo, on-site developed biomaterials.
\end{abstract}

Key words : Chemically bonded bioceramics, Ca-aluminate, Nanostructural integration, Dental, Orthopaedic and drug delivery carrier applications

\section{Introduction}

B iomaterials in general are based on a broad range of materials, such as organic polymers, metals and ceramics. ${ }^{1)}$ Typical metallic biomaterials are based on stainless steel, cobolt based alloys and titanium or titanium alloys, and amalgam alloys. Polymeric biomaterial composites are based on amides, ethylene, propylene, styrene, methacrylates and/or methyl methacrylates. Biomaterials based on ceramics are found within all the classical ceramic families: traditional ceramics, special ceramics, glasses, glass-ceramics, coatings and chemically bonded ceramics.

Classifications of ceramics in general and as biomaterials are presented in Table 1 and Fig. 1.

Most ceramics are formed at high temperatures through sintering processes. By using chemical reactions, the biomaterials in the chemically bonded systems, the CBBC-systems, can be produced at low temperatures (body temperature), which is attractive from several perspectives: cost, avoidance of gradients (thermal stress), dimensional stability and minimal negative effect on the system with which the materials interact. Notable is that hard tissue of bone and teeth is formed via biological chemical reactions, and in chemical composition close to certain of those of chemically bonded bioceramics.

Biomaterials can be made prior to use in the body in a con-

\footnotetext{
${ }^{\dagger}$ Corresponding author : Leif Hermansson

E-mail : leif.hermansson@doxa.se

Tel : +46-70-667-3450
}

ventional preparation of the material. The need for in situ, in vivo formed implant materials gives the chemically bonded ceramics (CBBC) especially good potential as biomaterials, for which injectability is a basic requirement. Injectable bioceramics belong to the CBBC-group, and are known as inorganic cements. These ceramics include room/body temperature formed biomaterials with excellent biocompatibility. They are based on phosphates, aluminates, silicates and/or sulphates. Depending on the in vivo chemical and biological stability, these biomaterials can be divided into three groups: stable, slowly resorbable and resorbable biomaterials. The choice for stable materials is Ca-aluminate based materials. ${ }^{2)}$ Slowly resorbable materials are found within Ca-silicates and Ca-phosphates, and fast resorbing materials among Ca-sulphates and some Ca-phosphates. The stable biomaterials are suitable for long-term use, loadbearing implants and osteoporosis-related applications. For trauma and treatment of younger patients, the preferred biomaterial is slowly resorbable material, which can be replaced by new bone tissue. ${ }^{4)}$

Ca-aluminate as a biomaterial has been evaluated for over three decades with regard to general physical, mechanical and biocompatible properties. Ca-aluminate based materials, due to their unique curing/hardening characteristics and related microstructure, exhibit a great potential within the biomaterial field. The paper aims to give an overview of the use of Ca-aluminate (CA) as a biomaterial within odontology and orthopaedics and as a carrier material for drug delivery. The examination deals with aspects such as the chemical composition selected, inert filler parti- 
Table 1. Classification of Ceramics and Examples of Bioceramics ${ }^{2}$

\begin{tabular}{ll}
\hline Ceramics-Classification & Examples of Bioceramics \\
\hline Traditional ceramics & Dental porcelain $\left(\mathrm{K}_{2} \mathrm{O}-\mathrm{Al}_{2} \mathrm{O}_{3}-\mathrm{SiO}_{2}\right)$ \\
Special ceramics & $\mathrm{Al}$-, $\mathrm{Zr}$ and Ti-oxides \\
Glass & Bioactive glasses $\left(\mathrm{Na}_{2} \mathrm{O}-\mathrm{CaO}-\mathrm{P}_{2} \mathrm{O}_{5}-\mathrm{SiO}_{2}\right)$ \\
Glass-ceramics & Apatite $\left(\mathrm{CaO}-\mathrm{P}_{2} \mathrm{O}_{5}-\mathrm{H}_{2} \mathrm{O}\right)$, Wollastonite $\left(\mathrm{CaO}-\mathrm{SiO}_{2}\right), \mathrm{Li}$-silicate based $\left(\mathrm{Li}_{2} \mathrm{O}-\mathrm{SiO}_{2}\right)$ and \\
Chemically Bonded Ceramics (CBBCs) & Leucite-based $\left(\mathrm{K}_{2} \mathrm{O}-\mathrm{Al}_{2} \mathrm{O}_{3}-\mathrm{SiO}_{2}\right)$ \\
\hline
\end{tabular}

\section{BIOMATERIALS

BIOCERAMICS BIOMETALS \\ BIOCERAMICS}

CHEMICALLY BONDED SINTERED CERAMICS GLASSES GLASS-CERAMICS

CHEMICALLY BONDED BIOCERAMICS (CBBCs)

BODY TEMPERATURE CBBCS

\section{BODY TEMPERATURE CBBCS}

ACID-BASE REACTION WATER UP-TAKE POLYMERISATION REACTION

Fig. 1. Classification of Bioceramics. ${ }^{3)}$

cles used, early properties during preparation and handling (working, setting, injection time, translucency, radio-opacity) and final long-term properties such as dimensional stability and mechanical properties including fracture toughness, compressive and flexural strength, hardness and Young's modulus.

This review article will also describe the close relation between Ca-aluminate and the body's own chemically bonded ceramics, the Ca-phosphates, the apatites. The structures of apatite in hard tissue are designed to meet requirements on the macro, micro and nano size levels with regard to the formation and mechanical properties. All structures are based on nanosize crystals and nanosize inter and intra layers. ${ }^{2,5)}$ See the example of a tooth in Table 2.

Hard tissue is basically divided into three major groups: enamel, dentine and bone structures (compact and spongy (trabecular or cancellous)). ${ }^{5)}$ The main purpose of hard tissue is to carry loads or to impart the ability to withstand mechanical stress. For dental tissues, enamel and dentine, resistance against wear and chemical attack are also important features. The hard chemical component in all hard tissues is apatite. Apatite can appear in nature and in living beings in several modifications, because the basic structure hydroxyapatite, $\mathrm{Ca}_{5}\left(\mathrm{PO}_{4}\right)_{3}(\mathrm{OH})$, easily forms solid solutions. ${ }^{6)}$ Examples are presented in Table 3.

The general chemical formula of apatite is $\left[\left(\mathrm{Me}^{2+}\right)_{\mathrm{x}}(\mathrm{di}-\right.$ or trivalent anion $\left.)_{y}(\text { monovalent anion })_{z}\right]$. Thus three main positions - one for cations and two for anions - are found within the apatite structure. The unit cell of apatite is $\mathrm{Ca}_{10}\left(\mathrm{PO}_{4}\right)_{6}(\mathrm{OH})_{2}$, why solid solutions of apatite in Table 2 can be summarised as $(\mathrm{Ca}, \mathrm{Mg})_{10}\left(\mathrm{PO}_{4}, \mathrm{CO}_{3}, \mathrm{HPO}_{4}\right)_{6}(\mathrm{OH}, \mathrm{Cl}, \mathrm{F})_{2}$. Other substituents in low concentrations are also possible, especially other metals such as $\mathrm{Sr}, \mathrm{Ba}, \mathrm{Na}, \mathrm{Li}, \mathrm{Mn}$ and $\mathrm{Zn}$.

Table 2. Tooth Structure Sizes - from $\mathrm{mm}$ to $\mathrm{nm}$

\begin{tabular}{ccccc}
\hline Tooth structure & Size in $\mathrm{mm}$ & Size in $\mu \mathrm{m}$ & Size in $\mathrm{nm}$ & Size in $\mathrm{nm}$ \\
\hline Whole tooth & 10 & - & - & - \\
Individual plates & - & 0.2 & 15 & - \\
Nanocrystals & - & - & - & 1.5 \\
\hline Single crystal within a nanocrystal & - & - & - \\
\hline
\end{tabular}

Table 3. Examples of Solid Solutions of Hydroxyapatite as Minerals and Biological Tissues

\begin{tabular}{cccc}
\hline Type of Apatite & Main formula & Major substituent(s) & Comments \\
\hline Hydroxyapatite $(\mathrm{HA})$ & $\mathrm{Ca}_{5}\left(\mathrm{PO}_{4}\right)_{3}(\mathrm{OH})$ & - & Basic structure \\
F-apatite & $\mathrm{Ca}_{5}\left(\mathrm{PO}_{4}\right)_{3}(\mathrm{OH}, \mathrm{F})$ & $\mathrm{F}$ & Mineral \\
Mineral OH-apatite & $\mathrm{Ca}_{5}\left(\mathrm{PO}_{4}\right)_{3}(\mathrm{OH})$ & - & Mineral \\
Dahllite & $\mathrm{Ca}_{5}\left(\mathrm{PO}_{4}, \mathrm{CO}_{3}\right)_{\mathbf{x}}(\mathrm{OH})_{\mathrm{y}}$ & $\mathrm{CO}_{3}$ & Mineral \\
Staffelite & $\mathrm{Ca}_{5}\left(\mathrm{PO}_{4}, \mathrm{CO}_{3}\right)_{\mathbf{x}}(\mathrm{OH}, \mathrm{F})_{\mathbf{y}}$ & $\mathrm{CO}_{3}, \mathrm{~F}$ & $\mathrm{Mineral}$ \\
Human enamel apatite & $(\mathrm{Ca}, \mathrm{Mg})_{\mathbf{x}}\left(\mathrm{PO}_{4}, \mathrm{HPO}_{4} \mathrm{CO}_{3}\right)_{\mathbf{y}}(\mathrm{OH}, \mathrm{Cl})$ & $\mathrm{Mg}, \mathrm{HPO}_{4}, \mathrm{CO}_{3}, \mathrm{Cl}$ & Biological apatite \\
Shark enameloid & $\mathrm{Ca}_{\mathbf{x}}\left(\mathrm{PO}_{4}, \mathrm{CO}_{3}, \mathrm{HPO}_{4}\right)_{\mathbf{y}}(\mathrm{OH}, \mathrm{F})$ & $\mathrm{F}, \mathrm{CO}_{3}$ and $\mathrm{HPO}_{4}$ & Biological apatite \\
\hline
\end{tabular}


In many chemically bonded bioceramic reactions, apatite structures are formed as extra phases. In chemically bonded bioceramics, such as hydrated Ca-aluminates and Ca-silicates, two of these three main positions are the same as those in apatite. An example for hydrated Ca-aluminates is the phase Katoite $\mathrm{Ca}_{3}\left[\mathrm{Al}(\mathrm{OH})_{4}\right]_{2}(\mathrm{OH})_{4}$.

Nanostructural chemically bonded bioceramics are so far found only within a few orthopaedic applications. Osteoporosis is by far the biggest cause of fractures. It affects an estimated 75 million people only in Europe, the US and Japan and the global prevalence is forecast to grow quickly. One in three women who have passed menopause will experience osteoporotic fractures, as will one in five men. There are an estimated two million osteoporotic fractures every year in the US and Europe. Vertebral Compression Fractures (VCFs) caused by low-energy trauma are increasingly common in osteoporotic patients. Current treatments for VCF are focused on vertebral body augmentation, i.e. strengthening of the vertebral body by injecting bone cement. Augmentation also potentially includes therapies aimed at the prevention of vertebral fractures and can involve the delivery of biologically active compounds in order to increase bone mass. The VCF market is dominated by two procedures: percutaneous vertebroplasty and kyphoplasty.

PMMA bone cement, under various brand names, is currently the dominant commercially available material for vertebroplasty and has been extensively characterized in the literature. ${ }^{7,8)}$ Although PMMA is recognized as a successful filler material, there are shared concerns in the field that it is not an optimal material, for several reasons. Disadvantages of PMMA have been identified as: 1) No biologic potential to remodel or integrate into the surrounding bone, 2) No direct bone apposition, 3) High polymerization temperature, 4) Potential monomer toxicity and 5) Low radiopacity.

With chemically bonded bioceramics (phosphates, sulphates and aluminates) ${ }^{9-16)}$ there is a significant opportunity for a VCF cement to exhibit: 1) High radiopacity, 2) High initial and predictable viscosity to improve safety during procedure, 3) Good integration with vertebral bone, 4) Hardening at reduced temperature, 5) Immediate stability, 7) Mechanical strength adapted for early and active rehabilitation, 8) High radiopacity, 9) Good integration with vertebral bone, 10) Hardening at reduced temperature, 11) Mechanical strength adapted for early and active rehabilitation and 12) A possibility to deliver active compounds. In this review, studies in vertebroplasty using PVP and KVPtechniques are presented using Ca-aluminate based materials.

\section{Materials and Methods}

\subsection{Materials}

The biomaterials discussed in this paper are part of the main three-phase diagram of inorganic cements. ${ }^{17}$ ) (See Fig.

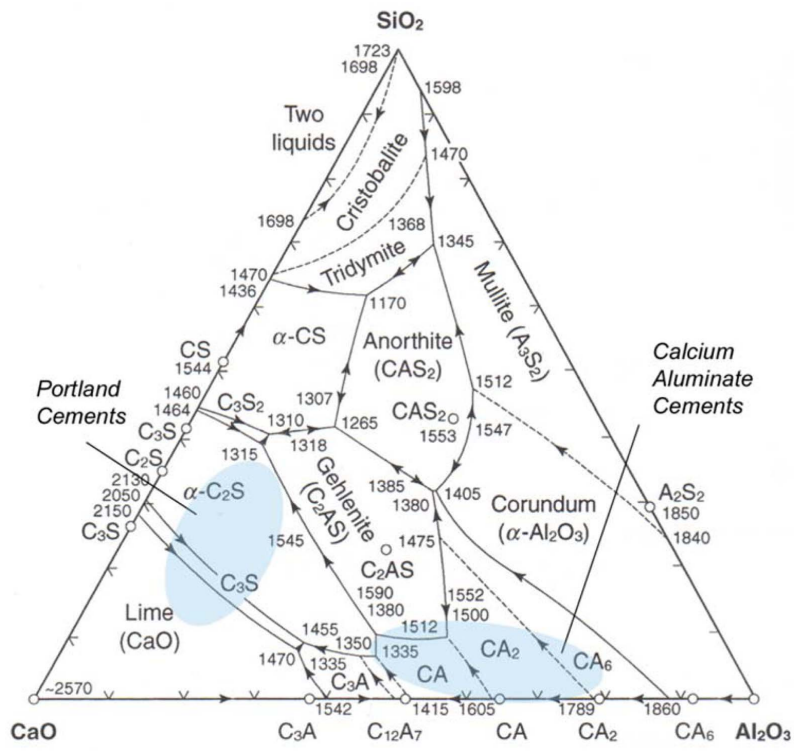

Fig. 2. Three phase diagram $\mathrm{CaO}-\mathrm{Al}_{2} \mathrm{O}_{3}-\mathrm{SiO}_{2}$.

2.) Several intermediate phases exist in the $\mathrm{CaO}-\mathrm{Al}_{2} \mathrm{O}_{3}$ system, and these use the cement chemistry abbreviation system $\mathrm{C}_{3} \mathrm{~A}, \mathrm{C}_{12} \mathrm{~A}_{7}, \mathrm{CA}, \mathrm{CA}_{2}$ and $\mathrm{CA}_{6}$, where $\mathrm{C}=\mathrm{CaO}$ and $\mathrm{A}=\mathrm{Al}_{2} \mathrm{O}_{3}$. Glass phases are also possible in this system. In the synthesis of Ca-aluminates, the Ca-source is lime, $\mathrm{CaO}$, an unstable alkaline compound, whereas $\mathrm{Al}_{2} \mathrm{O}_{3}$, one of the most stable materials, is the $\mathrm{Al}$-source. The reactivity of $\mathrm{Ca}$ aluminate phases decreases from $\mathrm{C}_{3} \mathrm{~A}$ to $\mathrm{CA}_{6}$. The $\mathrm{C}_{3} \mathrm{~A}$ phase is regarded as too reactive, with too high a reaction temperature for biomaterials; the $\mathrm{CA}_{2}$ and $\mathrm{CA}_{6}$ phases exhibit too low a reaction rate. For biomaterials, the greatest interest is related to a $\mathrm{CaO}-\mathrm{Al}_{2} \mathrm{O}_{3}$ molar ratio close to $1: 1$.

The Ca-aluminate phase used in the testing was in most studies the mono-calcium aluminate (CA), synthesized by the company Doxa AB, Sweden. The correct amounts of the raw materials are weighed into a suitable container. The powders are mixed by tumbling in excess isopropanol. Isopropanol is removed by evaporation of the solvent using an evaporator combining vacuum and heat, and mixture is finally heat-treated in an oven. The next step is filling high purity $\mathrm{Al}_{2} \mathrm{O}_{3}$ crucibles with the powder mix and heat treating it above $1300^{\circ} \mathrm{C}$ for the appropriate amount of time to achieve the phases. After crushing, the material is jet-milled to obtain fine-grained particles with mean particle size below $10 \mathrm{~mm}$ and $\mathrm{d}(99)$ below $15 \mathrm{~mm}$. The size should be less than approximately $10 \mathrm{~mm}$, since the penetration of water into hydrated bioceramics drops to almost zero after 10 micrometers.

Inert phases mixed with CA were glass particles or $\mathrm{ZrO}_{2}$, depending on the applications aimed at. For low viscosity and early hardening, a complementary glass ionomer can be used in some studies. ${ }^{18,19)}$ In some of the endodontic studies, the materials were based on a mixture of the Ca-phases CA and $\mathrm{CA}_{2}$ at the molar ratio $1: 1 .^{20)}$ 


\subsection{Methods}

2.2.1. Microstructure and General Properties

Methods used in the evaluation of the microstructure and general properties are summarised below. A more detailed presentation of the evaluation techniques is found in related papers published earlier. ${ }^{21-26)}$

Methods used in the evaluation of phase, elemental analyses and micro(nano)-structures were traditional SEM, TEM, HRTEM, XRD, XPS and STEM with EDX. To analyse interfaces and calcified tissue at the highest level, transmission electron microscopy (TEM) was used in combination with focused ion beam microscopy (FIB) for intact site-specific preparation of TEM-samples of very high site-specific accuracy. Cross-section TEM samples from the interface between hard tissue (enamel, dentine and bone) and biomaterial, e.g. a dental filling material, are produced by FIB. The system scans over a beam of positively charged gallium ions. The ions generate sputtered neutral atoms, secondary electrons and secondary ions. Here it is possible to increase the beam current of the primary ion beam and use the FIB as a fine-scale micro-machining tool to cut TEM samples with high accuracy. To produce the TEM-samples, the socalled "lift-out" technique can be used. The thickness of the samples used is approximately $150 \mathrm{~nm}$. This procedure is treated in detail in. ${ }^{27)}$

The materials were evaluated with regard to compressive strength (ISO 9917), biaxial flexural strength (ASTM F-394, flexural strength testing of ceramic materials) and Young's modulus (slope of compressive strength-strain curve) as functions of time when stored in phosphate buffer solution at body temperature. The mechanical properties were determined after $1 \mathrm{~h}, 24 \mathrm{~h}, 7$ days and 16 weeks. The compressive strength was measured on cylindrical samples with $4.7 \mathrm{~mm}$ diameter and more than $7 \mathrm{~mm}$ height. The flexural strength was measured on discs with $5 \mathrm{~mm}$ diameter and thickness of around $0.7 \mathrm{~mm}$. The fracture toughness was determined using an indentation technique.

The corrosion resistance test for dental materials - using a water jet impinging technique - was conducted according to EN 29917:1994/ISO 9917:1991, where removal of material is expressed as a height reduction using $0.1 \mathrm{M}$ lactic acid as solution, at $\mathrm{pH}$ 2.7. The test probe accuracy was $0.01 \mathrm{~mm}$. Values below $0.05 \mathrm{~mm}$ per $24 \mathrm{~h}$ of solution impinging are judged as acid resistant.

Dimensional stability was evaluated using the acrylic split pin method, as described in. ${ }^{18,28)}$ This method uses 200 $\times 30 \times 4 \mathrm{~mm}$ acrylic plates that have a central slit running from one side of the plate to a hole on the opposite side. Paste is placed in the hole and expansion is measured with an optical microscope according to the opening of the slit. The expanders with sample material are stored at $37^{\circ} \mathrm{C}$ in saturated humidity.

Standard tests used for evaluation of the dental luting cements are presented in Table 4.

\subsubsection{Biological and Clinical methods}

Table 4. Evaluation of Dental Luting Cements

\begin{tabular}{ll}
\hline \multicolumn{1}{c}{ Test } & \multicolumn{1}{c}{ Controlling standard } \\
\hline Net setting time & ISO 9917:2003 part 1 \\
Film thickness & ISO 9917:2003 part 1 \\
Compressive strength & ISO 9917:2003 part 1 \\
Acid erosion & ISO 9917:2003 part 1 \\
Radio Opacity & ISO 9917:2003 part 2 \\
In vitro bioactivity & By testing apatite formation \\
& in phosphate solution \\
\hline
\end{tabular}

The bodily acceptance of a biomaterial is a crucial issue, and to some extent the question has been solved by relating to the following toxicological endpoints, indicating biocompatibility as referred to in harmonized standard ISO 10993:2003, which comprises the following sections: Cytotoxicity (ISO10993-5), Sensitization (ISO10993-10), Irritation/Intra-cutaneous reactivity (ISO10993-10), Systemic toxicity (ISO10993-11), Sub-acute, sub-chronic and chronic toxicity (ISO10993-11), Genotoxicity (ISO10993-3), Implantation (ISO10993-6), Carcinogenicity (ISO10993-3) and Hemocompatibility (ISO10993-4). This is the main guideline when presenting the status of biocompatibility, but was complemented by corrosion testing, elementary analysis, $\mathrm{pH}$-change and additional cytotoxicity testing.

The example of a clinical study within orthopaedics, presented below, relates to a Ca-aluminate based biomaterial (Xeraspine) used in percutaneous vertebroplasty (PVP). PVP is a minimally invasive technique in which medical grade cement is injected into compressed fractures in order to relieve pain and provide stability. A large number of studies have shown that this treatment provides good pain relief and improved mobility, with an effect lasting for several years.

The conclusion of a pilot study in Germany of a Ca-aluminate based material, Xeraspine ${ }^{\circledR}$, in PVP on 8 patients with VCF, was that injection with Xeraspine ${ }^{\circledR}$ is a safe treatment of VCF that offers substantial and durable pain relief. Even with the promising pilot study results, data from a larger study was considered necessary to deepen knowledge of the product and to gain more experience of Xeraspine ${ }^{\circledR}$ as an injectable bioceramic.

The complete study comprises several aspects related to baseline actions, imaging, questionnaires, safety, surgery and laboratory work. A time table of the overall study is presented in Table 5 .

Interest in the haemocompatibility of bone cement and of injectable ceramic pastes has increased because of claimed risks of adverse coagulation as material may enter the blood system unexpectedly during injection into vertebral bodies, e.g. during vertebroplasty or kyphoplasty. The clotting behaviour of some common bone substitute materials that are used for or are candidates for vertebro- and kyphoplasty are presented below. The process that leads to thrombosis formation as blood contacts an artificial surface depends on 
Table 5. Schedule of Events indicating the Procedures Performed at Each Study Visit/Telephone Contact

\begin{tabular}{|c|c|c|c|c|c|c|c|c|}
\hline & Screening & Procedure & $\begin{array}{c}24 \\
\mathrm{~h}\end{array}$ & $\begin{array}{c}1 \\
\text { week }\end{array}$ & $\begin{array}{c}1 \\
\text { month }\end{array}$ & $\begin{array}{c}3 \\
\text { months }\end{array}$ & $\begin{array}{c}6 \\
\text { months }\end{array}$ & $\begin{array}{c}12 \\
\text { months }\end{array}$ \\
\hline Informed consent form & $x$ & & & & & & & \\
\hline Medical history & $x$ & & & & & & & \\
\hline Demo-graphy & $x$ & & & & & & & \\
\hline Radio-graphs & & $x$ & & & & & & \\
\hline $\mathrm{CT}$ & & & $x$ & & & & & \\
\hline MRI & $x$ & & & & & & & $x$ \\
\hline VAS & $x$ & & $x$ & $x$ & $x$ & $x$ & $x$ & $x$ \\
\hline Oswestry & $x$ & & $x$ & $x$ & $x$ & $x$ & $x$ & $x$ \\
\hline Mobility & $x$ & & $x$ & $x$ & $x$ & $x$ & $x$ & $x$ \\
\hline \multicolumn{9}{|l|}{ QoL } \\
\hline Use of analgesics & $x$ & & $x$ & $x$ & $x$ & $x$ & $x$ & $x$ \\
\hline $\begin{array}{l}\text { Safety* } \\
\text { A } \\
\text { B }\end{array}$ & $x$ & $\begin{array}{l}x \\
x\end{array}$ & $\begin{array}{l}x \\
x\end{array}$ & $\begin{array}{l}x \\
x\end{array}$ & $\begin{array}{l}x \\
x\end{array}$ & $\begin{array}{l}x \\
x\end{array}$ & $\begin{array}{l}x \\
x\end{array}$ & $\begin{array}{l}x \\
x\end{array}$ \\
\hline $\begin{array}{l}\text { Surgery* } \\
\text { C } \\
\text { D } \\
\text { E }\end{array}$ & & $\begin{array}{l}x \\
x \\
x\end{array}$ & & & & & & \\
\hline $\begin{array}{l}\text { Laboratory* } \\
\text { F }\end{array}$ & $x$ & & & & & & & $x$ \\
\hline $\begin{array}{l}\mathrm{CT}=\text { Computed tomogr } \\
\text { MRI = Magnetic Resona } \\
\text { VAS = Visual Analogue } \\
\text { QoL = Quality of Life }\end{array}$ & Imaging & $\begin{array}{l}* \text { Safety }, S u \\
\text { A }=\text { Adverse } \\
\text { B }=\text { Concom } \\
\text { C }=\text { ECG su } \\
\text { D }=\text { Oxygen } \\
\text { E }=\text { Handlin } \\
\text { F }=\text { Coagula }\end{array}$ & $\begin{array}{l}\text { anc } \\
\mathrm{nt} / \mathrm{S} \\
\mathrm{me} \\
\text { sion } \\
\text { rati } \\
\text { arac }\end{array}$ & $\begin{array}{l}\text { borator } \\
\text { Complic } \\
\text { ions } \\
\\
\text { tics } \\
\text { TSH }\end{array}$ & & & & \\
\hline
\end{tabular}

a range of factors related to the material and its surface characteristics, the rheology and the biological aspects commencing with the initial protein adsorption.

\section{Reactions including Nanostructures}

\subsection{Overall Reactions}

Chemically bonded ceramics are ceramics that formed due to chemical reactions, in many cases an acid-base reaction, in which the powder is the base and the water the weak acid. The precursor material is a ceramic powder (e.g. Casilicate or Ca-aluminate), which is "activated" in the waterbased liquid. A chemical reaction takes place in which the initial powder is partly or completely dissolved and new phases precipitate. The precipitated phases are composed of species from both the liquid and the precursor powder. The degree of reaction of the powder depends on the size of the precursor particles and/or the amount of water/liquid present, as well as the powder (p) to water (w) ratio (the $\mathrm{p} / \mathrm{w}$ ratio). The precipitates can be formed in situ in vivo, often in the nanoscale due to low solubility of the phases formed; details are presented below. The nanostructured chemically bonded bioceramics are especially found within the Caphosphate, Ca-aluminate and Ca-silicate systems. The large pores between the original dissolving precursor powders are, as the hydration continues, filled with nanocrystals, and the material hardens. The dissolution speed and the solubility products of the formed hydrate phases determine the nanosize, the setting time and final curing (hardening) of the material. The setting time can be controlled by selection of the precursor grain size and/or by addition of accelerating or retarding substances. Table 6 shows a typical time sequence of the different stages in the formation of chemically bonded dental bioceramics based on Ca-aluminate.

Since the material can be formed from a precursor powder mixed with a liquid, the material can be made moldable simply by controlling the amount of liquid (in relation to the powder) and by the possible addition of small amounts of polymers in the liquid. This makes the chemically bonded ceramics useful as injectable biomaterials, where the final

Table 6. Typical Time Sequence of the Formation of Chemically Bonded Ca-aluminate Bioceramics

\begin{tabular}{cccc}
\hline Dissolution and Repeated crystallization & Working and Setting time & Initial hardening & Ready to use \\
\hline Starts immediately & $5-15$ minutes & $5-20$ minutes & $5-60$ minutes \\
\hline
\end{tabular}


Table 7. Chemical Reactions of the CaO- $\mathrm{Al}_{2} \mathrm{O}_{3}-\mathrm{P}_{2} \mathrm{O}_{5}-\mathrm{H}_{2} \mathrm{O}(\mathrm{CAPH})$-System in Contact with Different Environment

\begin{tabular}{|c|c|c|}
\hline Reaction mechanism & Description & Comments \\
\hline Mechanism 1. Main reaction & $\begin{array}{l}3\left(\mathrm{CaO} \mathrm{Al}_{2} \mathrm{O}_{3}\right)+12 \mathrm{H}_{2} \mathrm{O} \rightarrow 3 \mathrm{Ca}^{2+}+6 \mathrm{Al}^{3+}+4(\mathrm{OH})^{-} \\
\rightarrow 3 \mathrm{Ca}^{2+}+6 \mathrm{Al}(\mathrm{OH})_{4}^{-} \\
\rightarrow \mathrm{Ca}_{3}\left[\mathrm{Al}(\mathrm{OH})_{4}\right]_{2}(\mathrm{OH})_{4} \text { (katoite) }+4 \mathrm{Al}(\mathrm{OH})_{3} \text { (gibbsite) }\end{array}$ & $\begin{array}{l}\text { Katoite and Gibbsite are formed } \\
\text { as the main nano-size hydrates }\end{array}$ \\
\hline $\begin{array}{l}\text { Mechanism 2. Complementary reaction } \\
\text { with phosphate-containing solution }\end{array}$ & $5 \mathrm{Ca}^{2+}+3 \mathrm{PO}_{4}^{3-}+\mathrm{OH}^{-} \rightarrow \mathrm{Ca}_{5}\left(\mathrm{PO}_{4}\right)_{3} \mathrm{OH}$ & $\begin{array}{l}\text { Additional phase formed: Nano- } \\
\text { size Apatite }\end{array}$ \\
\hline $\begin{array}{l}\text { Mechanism } 3 . \text { Contact zone reaction } \\
\text { with body liquid in presence of the basic } \\
\text { CA-phase }\end{array}$ & $\begin{array}{l}\mathrm{HPO}_{4}{ }^{2-}+\mathrm{OH}^{-} \rightarrow \mathrm{PO}_{4}{ }^{3-}+\mathrm{H}_{2} \mathrm{O} \text { Thereafter the apatite-forma- } \\
\text { tion reaction occurs as mechanism } 2 \\
5 \mathrm{Ca}^{2+}+3 \mathrm{PO}_{4}{ }^{3-}+\mathrm{OH}^{-} \rightarrow \mathrm{Ca}_{5}\left(\mathrm{PO}_{4}\right)_{3} \mathrm{OH}\end{array}$ & $\begin{array}{l}\text { Nanosize Apatite formation in } \\
\text { the contact zone in presence of } \\
\text { body liquid }\end{array}$ \\
\hline $\begin{array}{l}\text { Mechanism 4. Transformation reaction } \\
\text { of the originally formed phase Katoite. }\end{array}$ & $\begin{array}{l}\mathrm{Ca}_{3}\left(\mathrm{Al}(\mathrm{OH})_{4}\right)_{2}(\mathrm{OH})_{4} \rightarrow 2 \mathrm{Ca}^{2+}+\mathrm{HPO}_{4}^{2-}+2 \mathrm{H}_{2} \mathrm{PO}_{4}^{-} \\
\rightarrow \mathrm{Ca}_{5}\left(\mathrm{PO}_{4}\right)_{3}(\mathrm{OH})+2 \mathrm{Al}(\mathrm{OH})_{3}+5 \mathrm{H}_{2} \mathrm{O}\end{array}$ & $\begin{array}{l}\text { Nanocrystals of Apatite and } \\
\text { Gibbsite formed in the biomate- } \\
\text { rial contact zone towards tissue }\end{array}$ \\
\hline $\begin{array}{l}\text { Mechanism 5. Biologically induced inte- } \\
\text { gration and ingrowth }\end{array}$ & $\begin{array}{l}\text { Bone ingrowth towards the biomaterial contact area } \\
\text { allows the new bone structure to come into inte- } \\
\text { grated contact with the biomaterial. }\end{array}$ & $\begin{array}{l}\text { New bone formation at the con- } \\
\text { tact zone }\end{array}$ \\
\hline $\begin{array}{l}\text { Mechanism } 6 \text {. Mass increase reaction } \\
\text { due to presence of un-hydrated CA }\end{array}$ & $\begin{array}{l}3 \mathrm{CaO} \mathrm{Al} \mathrm{O}_{3}+12 \mathrm{H}_{2} \mathrm{O} \\
\rightarrow 3 \mathrm{CaO} \mathrm{Al}_{2} \mathrm{O}_{3} 6 \mathrm{H}_{2} \mathrm{O}+2 \mathrm{Al}_{2} \mathrm{O}_{3} 3 \mathrm{H}_{2} \mathrm{O}\end{array}$ & $\begin{array}{l}\text { Mass increase and point weld- } \\
\text { ing by water (liquid) up-take }\end{array}$ \\
\hline
\end{tabular}

biomaterial is formed in-situ in vivo. The chemistry, including phases formed and the structures obtained with chemically bonded bioceramics in contact with hard tissue, facilitates and improves the connection between the biomaterial and biological tissue. In many cases a nano-structural integration occurs.

Six different mechanisms have been found to be involved in the hydration and curing of chemically bonded bioceramics in the Ca-aluminate body liquid system. ${ }^{24)}$ The biomaterials will be in contact with different tissue -- enamel, dentine and hard bone tissue and soft tissue -- as well as other biomaterial contact surfaces. These six mechanisms affect the integration differently depending on a) what type of tissue the biomaterial is in contact with, b) in what state (un-hydrated or hydrated) the biomaterial is introduced, and c) what type of application is aimed at. The actual contact zone developed depends on a combination of these mechanisms and on the surrounding tissue. The latter varies from a cellular-free high content apatite tissue in the case of a dental enamel, via dentine, to a bone structure with cellular and body liquid contact. Both a pure nanostructural, mechanically controlled integration, and a chemically induced integration have been found. Table 7 below presents a summary of the six mechanisms involved in the integration of Calcium Aluminate materials towards tissues and implant surfaces.

The great amount of water uptake during hydration in the CBBC- systems is presented in Table 8 below. ${ }^{2)}$
Notable is the possible high water uptake in the Ca-aluminate system, which facilitates use of different viscosity for different applications.

\subsection{Nanostructure Development}

The nanostructures developed in some of the chemically bonded ceramic systems, especially the $\mathrm{CaO}-\mathrm{Al}_{2} \mathrm{O}_{3}-\mathrm{H}_{2} \mathrm{O}$ $(\mathrm{CAH}), \mathrm{CaO}-\mathrm{SiO}_{2}-\mathrm{H}_{2} \mathrm{O}(\mathrm{CSH})$ and the $\mathrm{CaO}-\mathrm{P}_{2} \mathrm{O}_{5}-\mathrm{H}_{2} \mathrm{O}(\mathrm{CPH})$ systems, are consequences of the low solubility product of the phases formed in these systems, ${ }^{26,29)}$ see Table 9 .

These values correspond to ion concentrations of approximately $10 \mathrm{mM}$ or less. The solubility of apatite (ss) is the lowest of all these possible phases. This means that in the presence of phosphate ions in contact with the basic system of Ca-aluminate or Ca-silicate, possible apatite formation is likely, and even in fact difficult to avoid. The hydrogen

Table 9. Solubility Products of Some of the Phases in the CAH, $\mathrm{CSH}$ and $\mathrm{CPH}$ Systems

\begin{tabular}{ccc}
\hline Phase & $\mathrm{pKs}$ & System \\
\hline Octacalcium phosphate & 48.5 & $\mathrm{CPH}$ \\
Hydroxyapatite & 58.5 & $\mathrm{CPH}$ \\
Fluoro apatite & 59.7 & $\mathrm{CPH}$ \\
Katoite & 22.3 & $\mathrm{CAH}$ \\
Gibbsite & 32.2 & $\mathrm{CAH}$ \\
Tobermorite & - & $\mathrm{CSH}$ \\
\hline
\end{tabular}

Table 8. Water Uptake during Hydration in the Ca-phosphate (CP), the Ca-aluminate (CA) and the Ca-silicate(CS) Systems

\begin{tabular}{ccccc}
\hline System & Typical Phase(s) & Oxide formula & Mol-\% $\mathrm{H}_{2} \mathrm{O}$ & \multicolumn{2}{c}{ Weight-\% Hydrated } \\
Product
\end{tabular}



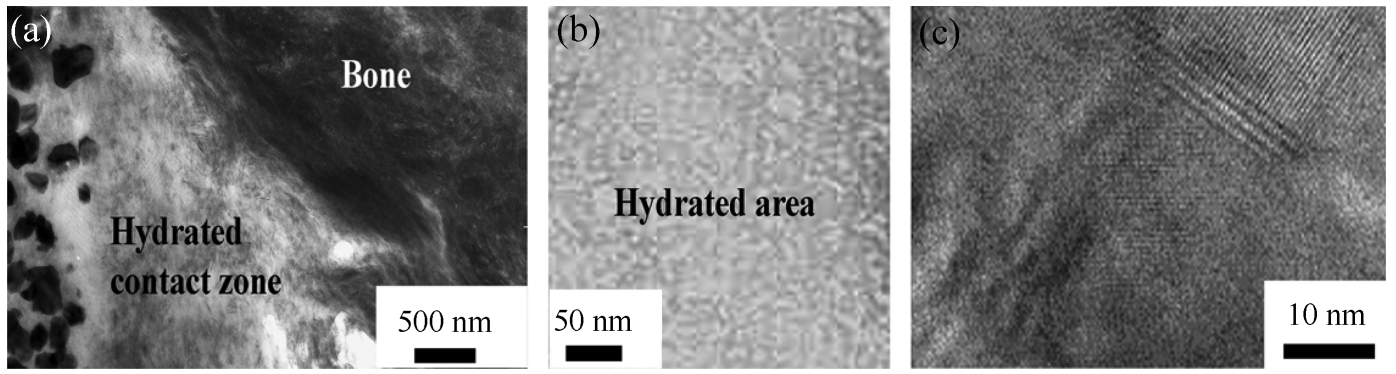

Fig. 3. Micro/nanostructure of Ca-aluminate material, (a) contact zone to bone, black particles to the left are inert zirconia particles, (b) hydrated contact close to tissue, and (c) nano-size structure of hydrated materials.

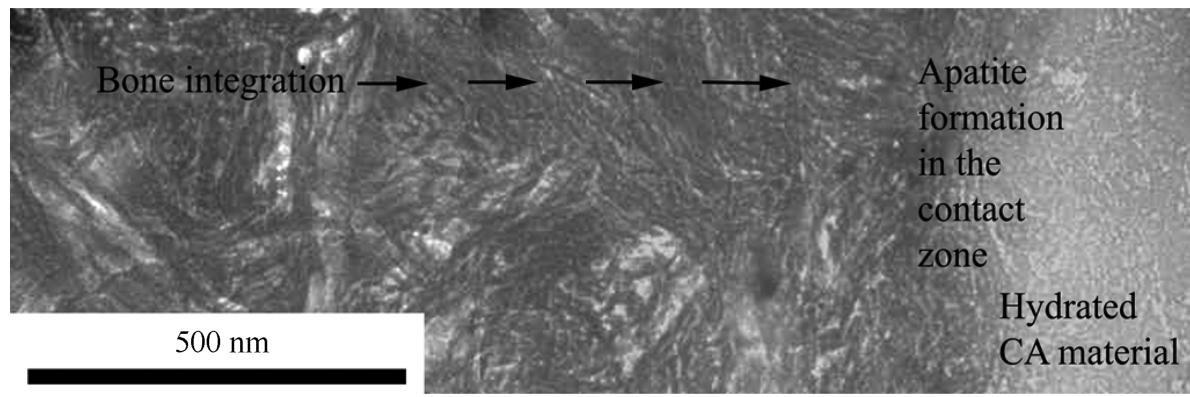

Fig. 4. Integration in the contact zone in the biomaterial system CASPH. ${ }^{24)}$

phosphates of the body liquid, $\mathrm{HPO}_{4}{ }^{2-}$ and $\mathrm{H}_{2} \mathrm{PO}_{4}^{-}$, are reduced to pure phosphate ions, $\mathrm{PO}_{4}{ }^{3-}$. Due to the extremely low solubility product of apatite $\left(\mathrm{pK}_{\mathrm{s}}=10^{-58}\right)$ precipitation of apatite occurs upon the originally precipitated nanocrystal of the main system.

The general nanostructure of the Ca-aluminate biomaterial system in contact with bone (CAPH) is shown in Fig. 3 below. ${ }^{24)}$

When apatite is formed at the interface according to any of reaction mechanisms 2 - 4 above, at the periphery of the bulk biomaterial, the biological integration may start. Bone ingrowth towards the apatite allows the new bone structure to come into integrated contact with the biomaterial. This is

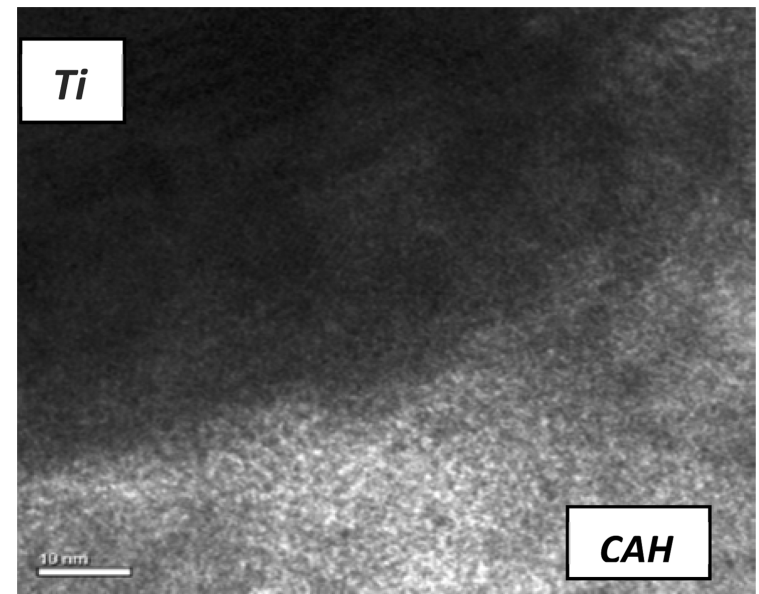

Fig. 5. Nanostructure integration at the contact zone between a titanium implant (Ti) and a Ca-aluminate hydrated paste $(\mathrm{CAH})$; High-resolution TEM $(\mathrm{bar}=10 \mathrm{~nm})$. an established fact for apatite interfaces. For the CA-system, the ingrowth is shown in Fig. 4. The transition from tissue to biomaterial is smooth and intricate. ${ }^{24)}$

A consequence of the nanostructure developed is that the CAPH-system also easily develops extremely good contact zones to other biomaterials. In Fig. 5 is shown the case for a Ti-implant. ${ }^{30}$

\subsection{Bioactivity and Antibacterial aspects}

In all the three main chemically bonded bioceramic systems of Ca-phosphates, Ca-aluminates and Ca-silicates, bioactivity is observed; the reason for this can be summarised as follows:

- The chemical similarity between the hydrated phases in Ca-aluminate and $\mathrm{Ca}$-silicate systems and the apatite phase in hard tissue

- The possibility of obtaining nanostructures in the biosystems in the same size range as that of apatite crystals in hard tissue

- The phase transformation of katoite into apatite and gibbsite (Mechanism 4, Table 6)

- The close contact between the biomaterial and hard tissue due to the repeated precipitation of nanocrystals upon all surfaces including those of hard tissues.

The nanostructure, including nanoporosity, developed in these biomaterial systems at near complete hydration conditions yields some unique properties related to how bacteriostatic and antibacterial properties develop in the biomaterial. ${ }^{31,32)}$ Based on several studies, the following general reasons/conditions have been identified that describe 
Table 10. Conditions Related to Antibacterial Features of Ca-aluminate Based Biomaterials

\begin{tabular}{ccc}
\hline Condition & Description & Comments \\
\hline $\mathrm{pH}$ & Acidic or alkaline $\mathrm{pH}$ interval & Antibacterial effect at $\mathrm{pH}<6$ and at $\mathrm{pH}>9$ \\
Encapsulation & Entrapping of bacteria & Bacterial growth inhibition \\
Surface structure & Fastening of bacteria upon the structured surface & Bacterial growth inhibition \\
F-ion presence & F-ions act as OH-ions & Antibacterial effect even at neutral conditions \\
\hline
\end{tabular}

and to some extent explain the bacteriostatic and even antibacterial features of the Ca-aluminate based biomaterials. These are summarized in Table 10.

The seemingly unlikely simultaneous appearance of bioactivity and antibacterial properties of Ca-aluminate based biomaterials is thus a reality.

\section{Application Field of Nanostructured Ca-aluminate Bioceramics}

\subsection{Application possibilities}

A summary of the application possibilities of the nanostructured bioceramics in the Ca-aluminate system is presented below. The potential for these ceramics is great and, besides dental applications, these bioceramics have also been studied as candidate materials for orthopaedic and drug delivery carrier systems. Especially interesting are the possibilities of chemically bonded ceramics producing in situ in vivo products.

For successful implantation of implants in bone tissue, early stabilisation is of great importance. Even small gaps may lead to relative micro-motions between implant and tissue, which increases the risk of implant loosening over time due to formation of zones of fibrous tissues at the implant-tissue interface. Early loading of implants is of particular interest for dental implants. The use of surface coating technology is today an established method to reduce the problem of poor interfacial stability of implants. With coating technology, structural characteristics of the implant (e.g. strength, ductility, low weight or machinability) may be combined with surface properties promoting tissue integration. ${ }^{30)}$

One promising feature in the coating technology for Caaluminates is related to mechanism 6 point-welding, shown in Table 4 above. Point-welding is defined as the possibility of early adaption to the implant surface and the hard tissue by increase of the coating material volume by interaction with the contact liquid. The coating material has a certain amount of un-reacted chemically bonded bioceramic, and this part includes body liquid into the formed contact zone material. This contributes to an early fill-up of the void between the original coating material and the tissue wall. Thereafter, tissue integration can take place.

A further area with high potential is additive manufacturing. Here, the possibility, among others, is to use the same kind of materials as implants and as cements.

\subsection{Dental applications}

The biomaterial of the $\mathrm{CaO}-\mathrm{Al}_{2} \mathrm{O}_{3}-\mathrm{H}_{2} \mathrm{O}$ system, when introduced into the body as a dental material, is in most cases a paste. The main reaction (Mechanism 1, Table 6 above)) involves precipitation of nanocrystals on contact areas and within the injected material. Repeated precipitation occurs until the original powder or the water is consumed, resulting in closing of cavities, gaps and voids. This together with the general properties of Ca-aluminate based biomaterials opens up multipurpose uses as a biomaterial in many different applications (cements, dental fillings, endodontic fillings, sealants, coatings or augmentation products) depending on the selection of the chemically bonded ceramic cement system. Due to reduced porosity based on the huge water uptake ability, the Ca-aluminate materials exhibit the highest strength among the chemically bonded ceramics. The inherent flexural strength is above $100 \mathrm{MP}$, based on measurement of the fracture toughness, which is about $0.7-0.8 \mathrm{MPam}^{1 / 2}$. The actual flexural strength is controlled by external defects introduced during handling and injection of the material. Table 11 presents typical property data.

Table 11. Mean property data of dental Ca-aluminate based materials $^{18,19,33,34)}$

\begin{tabular}{lcc}
\hline Property & $\begin{array}{c}\text { Typical } \\
\text { value }\end{array}$ & Interval* \\
\hline Compression strength, $\mathrm{MPa}$ & 150 & $60-270$ \\
Young's modulus, $\mathrm{GPa}$ & 15 & $10-20$ \\
Thermal conductivity, $\mathrm{W} / \mathrm{mK}$ & 0.8 & $0.7-0.9$ \\
Thermal expansion, ppm/K & 9.5 & $9-10$ \\
Flexural strength, MPa & 50 & $20-80$ \\
Fracture toughness, MPam ${ }^{1 / 2}$ & 0.5 & $0.3-0.8$ \\
Corrosion resistance, water jet & $<0.01$ & - \\
impinging, reduction in mm & 1.5 & $1.4-2.5$ \\
Radio-opacity, mm & $>30$ & $30-70$ \\
Process temperature, ${ }^{\circ} \mathrm{C}$ & 3 & $<4$ \\
Working time, min & 5 & $4-7$ \\
Setting time, min & 20 & $10-60$ \\
Curing time, min & 15 & $5-60$ \\
Porosity after final hydration, $\%$ &
\end{tabular}

*The interval is primarily related to the c/w ratio used; the highest values are achieved with $\mathrm{c} / \mathrm{w}$ ratio close to that of complete hydration with no excess of water 


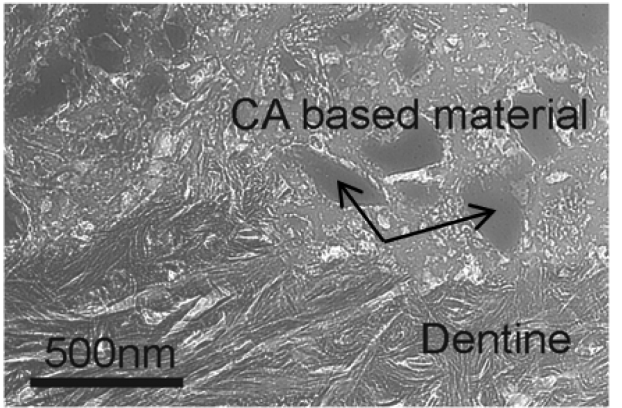

Fig. 6. Ca-aluminate based material in contact zone to dentine.

The thermal and electrical properties of Ca-aluminate based materials are close to those of hard tissue. Another important property related to Ca-aluminate materials is the possibility to control the dimensional change during hardening. In contrast to the shrinkage behaviour of many polymer-based biomaterials, the Ca-aluminates exhibit a small expansion, $0.1-0.3$ linear-\%. ${ }^{18)}$

The nature of the mechanisms utilized by Ca-aluminate materials (especially Mechanism 1, see Table 6 above), when integrating and adhering to tooth tissue and other materials, makes these materials compatible with a range of other dental materials, including resin composite, metal, porcelain, zirconia, glass ionomers and gutta-percha. This expands the range of indications for nanostructured chemically bonded bioceramic products from not only those involving tooth tissue, e.g. cavity restorations, but also to a range of other indications: dental cement, liner/base, base and core build-up and endodontic sealer/filler materials, which involve contact with materials such as porcelain, oxides and polymers and metals, and coatings on dental implants such as titanium or zirconia-based materials. Fig. 6 shows an experimental dental filling Ca-aluminate based material in connection with dentine. ${ }^{35)}$ The arrows indicate inert additive glass particles.

Below is a picture of a new dental luting cement, Ceramir ${ }^{\circledR} \mathrm{C} \& \mathrm{~B}$, in this case with PFM crowns. More details are presented in. ${ }^{36,37)}$

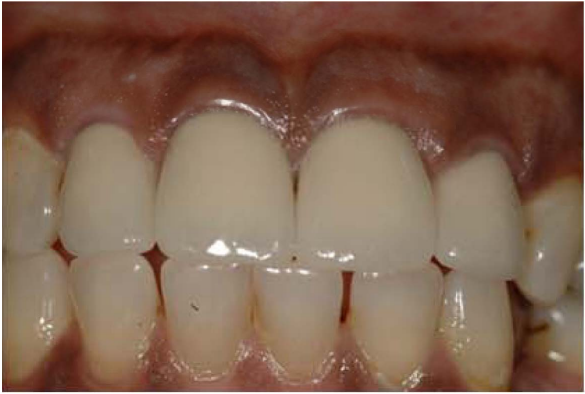

Fig. 7. Clinical digital photograph of maxillary anterior restorations, (right and left lateral and central incisors cemented by Ceramir $\left.{ }^{\circledR} \mathrm{C} \& \mathrm{~B}\right)$.

Figure 8 shows examples of X-ray examination of orthograde and retrograde treatments using an experimental Ca-aluminate based nanostructured material. ${ }^{20)}$

\subsection{Orthopaedic applications within Ca-aluminate bioceramics}

The apatite based biomaterials are excellent for bone void filling but still lack strength for load bearing applications. Other aspects of the use of apatite or Ca-phosphates biomaterials are related to handling, hardening time and shelf life. These are studied among other ideas in a Ph.D. Thesis by Åberg. ${ }^{38)}$

For load bearing applications within orthopaedics, nanostructured chemically bonded bioceramics such as Ca-aluminate, with higher strength than other CBBCs, may be options. Within orthopaedics the following areas for Ca-aluminate biomaterials have been identified: percutaneous vertebroplasty (PVP) and kyphoplasty (KVP) and general augmentation. ${ }^{14-16)}$

The rate of the hydration is controlled by: 1) the cement phase, 2) the particle size of the cement, 3) the hydration temperature and 4) processing agents. Aspects of temperature rise are especially important when larger amounts of injectable materials are necessary, as for some orthopaedic applications.

The PVP and KVP techniques are described briefly below. Percutaneous vertebroplasty (PVP): PVP is predomi-

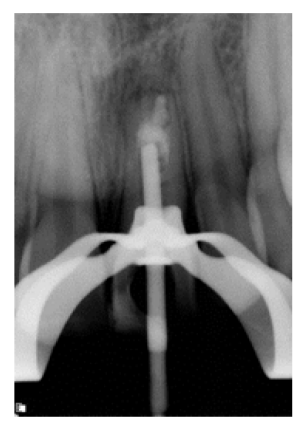

(a)

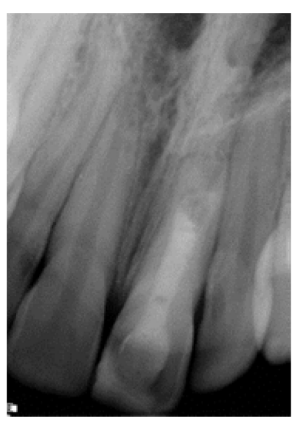

(b)

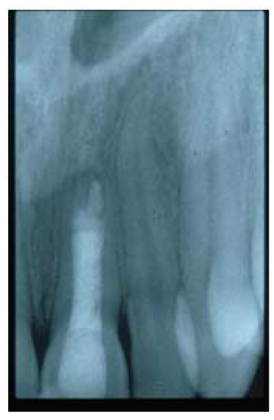

(c)

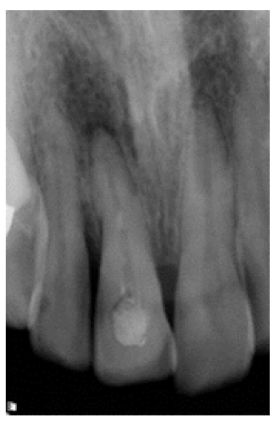

(d)

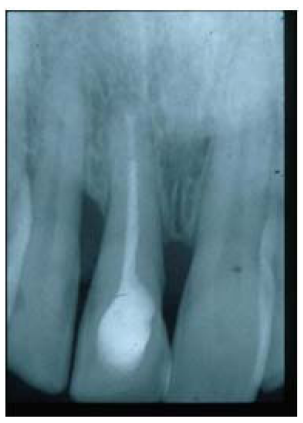

(e)

Fig. 8. Orthograde filling, tooth 21; condensing with a Gutta-percha pointer (a), just after treatment (b), at two years control (c), and Retrograde filling, tooth 21 at treatment (d) and at two years control (e). 
nantly performed under local anesthesia by interventional radiologists. The material is injected directly into the fractured vertebra to stabilize it and relieve pain.

Kyphoplasty (KVP): KVP is predominantly performed under anesthesia by orthopedic surgeons and neuro-surgeons but increasingly also by interventional radiologists. The fracture of the collapsed vertebra is reduced by inflating a balloon inside it. After deflation and removal of the balloon the stabilizing material is injected.

Calcium aluminate based material is highly mouldable, making it applicable to orthopaedic cavities with standard syringes and needles. The injectability of the chemically bonded ceramics is mainly controlled by water added as the reacting phase with the powdered cements. This reaction is an acid-base reaction in which water acts as a weak acid and the cement powder as a base. The technological importance of this is that all the water needed for injectability can be consumed in the formation of solid phases, yielding products with low porosity, one of the requirements for high strength. The paste may cure within about 5 minutes at $37^{\circ} \mathrm{C}$ and develops strength values comparable to those of PMMA bone cement. The cured material is long-term stable and shows promisingly good biocompatibility. The benefits of injectable ceramic biomaterials based on Ca-aluminate related to orthopedic applications are during surgical procedures: 1) High radiopacity allows for superior visibility of the cement and increases the probability of detecting potential leakage during injection (See Fig. 9 below), 2) High and linearly increasing viscosity reduces the risk of leakage and yields predictable handling, 3) High cohesiveness optimizes the cement's filling pattern in the vertebrae and 4) material is non-toxic and produces no fumes; ${ }^{12,39)}$ after the procedure, benefits are: 1) High mechanical strength, 2) Biocompatibility including biological integration and 3) Long-term stabil-

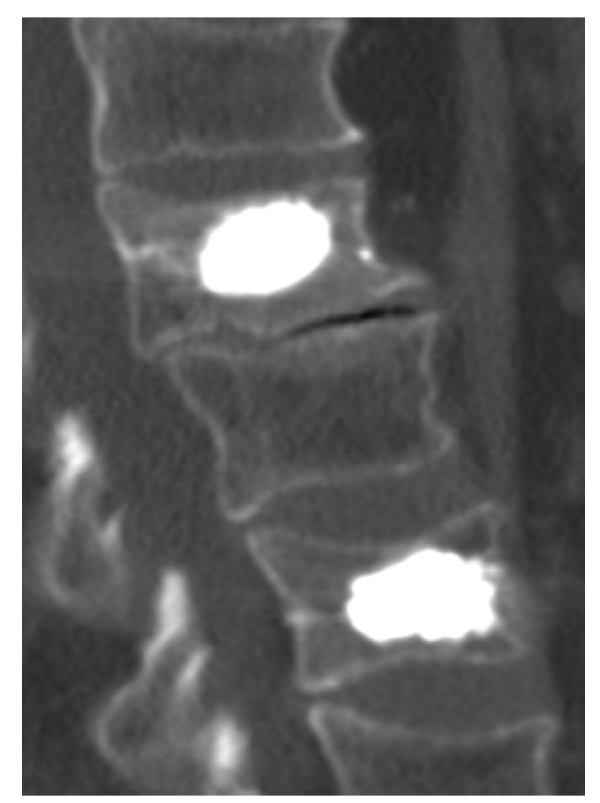

Fig. 9. Vertebral compression fractures, restored by Ca-aluminate based material.

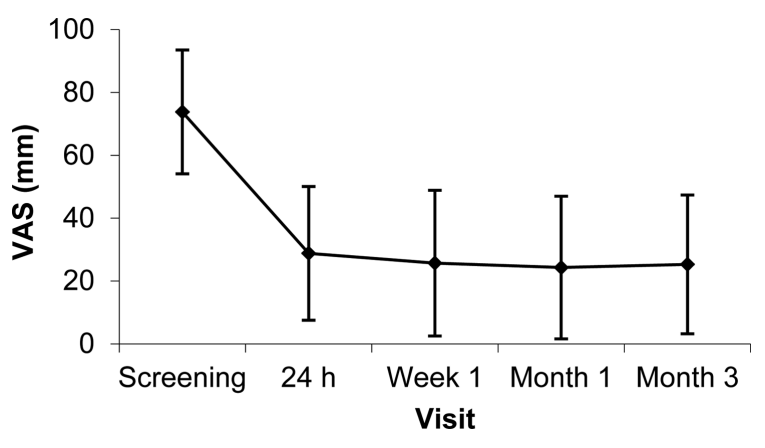

Fig. 10. Pain at rest measured by VAS at screening and after the procedure.

ity, i.e. non-resorbable system. ${ }^{12,40)}$

The amount of back pain at rest corresponding to the level of VCF was to be rated by the patient by placing a vertical mark on a $100 \mathrm{~mm}$ VAS with the extremes 'No pain' (0) and 'Worst possible pain' (100). At screening, the patients presented back pain within an interval of $2-100 \mathrm{~mm}$ VAS and a mean of $73.8 \mathrm{~mm}$ VAS. Within $24 \mathrm{~h}$ of Xeraspine ${ }^{\circledR}$ PVPtreatment, the mean VAS at rest was reduced to 28.8. A slight additional pain reduction was seen at 1 week after the procedure and pain remained unchanged throughout the 3 months studied. See Fig. 10 below.

At six and 12 months, the VAS results were in the same range as for Month 3. This was also the case for the VAS results in the KVP-process.

The interest in the haemocompatibility of bone cement and the injectable ceramic pastes has increased because of claimed risks of adverse coagulation as material may enter the blood system unexpectedly during injection into vertebral bodies, e.g. during vertebroplasty or kyphoplasty. The clotting behaviour of some common bone substitute materials, which are used for or are candidates for vertebro- and kyphoplasty, is presented below. The process that leads to thrombosis formation as blood contacts an artificial surface depends on a range of factors coupled to the material and its surface characteristics, the rheology and the biological aspects, commencing with the initial protein adsorption.

Four orthopaedic cements, a polymethylmetacrylate (traditional bone cement) and three calcium-based ceramic cements were tested using a close circuit Chandler loop model with the inner surfaces of the PVC tubing coated with heparin. The model exposes the test materials to fresh human whole blood. A special procedure was developed to evaluate the solidifying of pastes in the Chandler loop model. This procedure covers a section of the inner wall of the tubing with a thin layer of non-cured cement paste. Thereafter, the tubing is filled with fresh whole blood and the loop is closed. The loops are rotated at $32 \mathrm{rpm}$ in a $37^{\circ} \mathrm{C}$ water bath for 60 minutes. The cements are cured in contact with the flowing blood.

After incubation, the blood and the material surfaces were investigated with special attention to clotting reactions. Blood samples were collected and supplemented with EDTA 
for cell count analysis. Blood from the loops was centrifugated to generate plasma for analysis of thrombin-antithrombin complex (TAT), C3a and TCC complement marker. It is concluded that the clotting behaviour of the Ca-aluminate based cement and the PMMA is considerably lower than that of the calcium phosphate and sulphate materials in these tests. More details about the test method are described in. ${ }^{32)}$

The PMMA and Ca-aluminate biocement both seemed relatively unaffected by the blood test. Both materials remained clad to the tubing inner wall. The Calcium phosphate-material and the Calcium sulphate materials, however, had interacted strongly with the blood and formed blood-ceramic material mixtures that largely filled the lumen of the tubing. The remaining material was found collected in large lumps of thrombosis, which were found loose in the tubing.

\subsection{Drug Delivery Carrier Applications}

The ceramic carrier chemistry allows for loading of almost any medicament. The drugs can be favorably loaded in the water-liquid, in the pore system of inert filler particles and in processing agents. Thus, drugs can be loaded both during formation of hydrates, or after hydration by infiltration. For hydrophobic medical agents, the agent can be easily mixed into the precursor powder or together with a second ceramic filler. The nanoporous materials are sometimes divided into micro- $(<2 \mathrm{~nm})$, meso- $(2-10 \mathrm{~nm})$ and macro- $(<10 \mathrm{~nm})$ porosity. General aspects of materials as drug carriers are treated in other papers., ${ }^{1,41-44)}$

The carrier material system described exhibits well-controlled microstructures on the nano-size level, which lend the carrier material opportunities for selected and controlled release of the medicament. The release time is controlled mainly by the contents of the hydrated chemically bonded cement phases: the higher the content of the cement, the longer the release time. The longest release time is achieved for fully hydrated phases with water contents close to the water to cement ratio (w/c) required for complete hydration.

By introducing optional additives, or by changing the w/c ratio, the release time can be controlled from a few hours to more than one day. The release time is also dependent on where the drug is placed in the body. In cortical bone, a release time of months seems possible.

The carrier may be used as a vehicle for transport and delivery of the medicament as an injectable implant. The combination of the material as carrier and implant material makes site-specific placement of drugs and implants possible.

The amount of drug released in a specific case is controlled by the amount of drug in the carrier, and how the carrier material is designed. Using the mixed powder cement and an inert phase opens up the possibility of combined drugs, e.g. for rapid release based on the inert phase, medium release rate based on partially hydrated phases, and slow release based on fully hydrated cement phases.

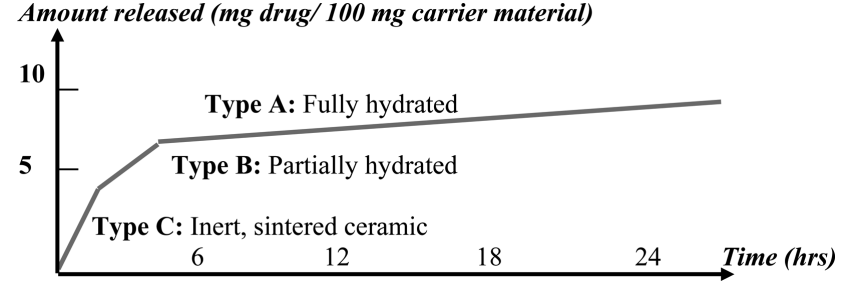

Fig. 11. Schematic release of drugs using different pore structures.

Test materials have been used with loading of the drugs in the interval $1-10 \mathrm{mg} / 100 \mathrm{mg}$ carrier material. Fig. 10 shows schematically the release rates obtained using the corresponding selected pore structures of the carrier material.

\section{Conclusion and Outlook}

The interesting and unique properties of the Ca-aluminate systems during hydration and as permanent implant materials are due to their similarity in chemical features to apatite; properties can be summarised as follows:

- Chemical similarity between the hydrated phases in the $\mathrm{CaO}-\mathrm{Al}_{2} \mathrm{O}_{3}-\mathrm{H}_{2} \mathrm{O}$ system and apatite phases in hard tissue

- Possibility of obtaining nanostructures in biomaterials of the same size range as that of apatite crystals in hard tissue

- Close contact between biomaterial and hard tissue due to the repeated precipitation of nanocrystals on all surfaces including those of hard tissues; nanostructured integration

- No bonding to tissue or other biomaterials needed

- Antibacterial properties even at pH close to neutral

- Dimensional stability during hydration; no shrinkage

- No dry field precaution; the described biomaterials are developed in water-containing liquid

- Environmental friendliness

These features of the Ca-aluminate materials and the established biocompatibility and bioactivity of these nanostructured biomaterials open them up for multipurpose biomaterial use.

Dental applications: Dental cements, endodontic products (orthograde and retrograde), sealants, pedodontic fillings, regular fillings, dental implant coatings, and an area with reference to additive manufacturing. Here the possibility, among others, is to use the same kind of materials as implants and as cements.

Orthopaedic applications: Percutaneous vertebroplasty, kyphoplasty, implant coatings and bone void fillings.

Drug delivery carrier applications: The chemistry allows loading of different medicaments within a broad time interval for delivery, from hours to months.

Third generation nanostructured Biomaterials: For 
even more biologically related nanostructured bioceramics, stem cell produced materials are expected. However, a restriction is the time before the cells in the biomaterial can be used. That is why the combination of nanostructured chemically bonded bioceramics and stem cell activity is likely in the development of the third generation biomaterials, especially if load-bearing properties are required.

\section{Acknowledgments}

The author thanks Irmeli Hermansson at Applied Research Sweden AB, and the personnel at Doxa Company, the Materials Science Department at Uppsala University, and the Center for Dental Technology and Biomaterials, Karolinska Institute, for valuable input over a three-decade period.

\section{REFERENCES}

1. J. Park and R. S. Lakes, Biomaterials: An Introduction; Springer, 2007.

2. L. Hermansson, "Nanostructural Chemically Bonded Caaluminate Based Biomaterials," pp. 47-74 in Biomaterials - Physics and Chemistry, Ed. by R Pignatello, InTech, Rijeka, 2011.

3. L. Hermansson, "Classification and Summary of Beneficial Features of Nanostructural Chemically Bonded Bioceramics," pp. 133-37 in Nanostructural Bioceramics: Advances in Chemically Bonded Ceramics, CRC Press, Boca Raton, 2015.

4. L. L. Hench, "Biomaterials: A Forecast for the Future," Biomaterials, 19 [6] 1419-23 (1998).

5. R. B. Martin, "Bone as a Ceramic Composite Material," Mater. Sci. Forum, 293 5-16 (1999).

6. S. R. Simon, Orthopaedic Basic Science; Amer Academy of Orthopaedic, 1994.

7. P. F. Heini and U. Berlemann, "Bone Substitutes in Vertebroplasty," Eur. Spine J., 10 205-13 (2001).

8. I. H. Liebermann, D. Togawa, and M. M. Kayanja, "Vertebroplasty and Kyphoplasty: Filler Materials," Spine J., 5 305-16 (2005).

9. M. Bohner, "Calcium Ortophosphates in Medicine: from Ceramics to Calcium Phosphate Cements," Injury, 31 [4] 37-47 (2000).

10. H. Engqvist, M. Couillard, G. A. Botton, M. W. Phaneuf, N. Axén, N.-O. Ahnfelt, and L. Hermansson, "In vivo Bioactivity of a Novel Mineral Based Orthopaedic Biocement," Trends Biomater. Artif. Organs, 19 27-32 (2005).

11. T. Jarmar, T. Uhlin, U. Höglund, P. Thomsen, L. Hermansson, and H. Engqvist, "Injectable Bone Cements for Vertebroplasty Studied in Sheep Vertebrae with Electron Microscopy," Key Eng. Mater., 361-363 373-76 (2008).

12. H. Engqvist, S. Edlund, G. Gómez-Ortega, J. Loof, L. Hermansson, "In Vitro Mechanical Properties of a Calcium Silicate Based Bone Void Filler," Key Eng. Mater., 309311 829-32 (2006).

13. A. Faris, H. Engqvist, J. Lööf, M. Ottosson, and L. Hermansson, "In Vitro Bioactivity of Injectable Ceramic
Orthopaedic Cements," Key Eng. Mater., 309-311 833-36 (2006).

14. H. Engqvist, T. Persson, J. Lööf, A. Faris, and L. Hermansson, "Chemical Stability of a Novel Bioceramic for Stabilisation of Vertebtal Compression," Trends Biomater. Artif. Organs, 21 [2] 98-106 (2008).

15. J. Lööf, A. Faris, L. Hermansson, and H. Engqvist, "In Vitro Biomechanical Testing of Two Injectable Materials for Vertebroplasty in Different Synthetic Bone," Key Eng. Mater. 361-363 369-72 (2008).

16. K. Breding and H. Engqvist, "Strength and Chemical Stability due to Aging of Two Bone Void Filler Materials," Key Eng. Mater., 361-363 315-18 (2008).

17. A. Muan and E. F. Osborn, Phase Equilibria among Oxides in Steelmaking; Addison-Wesley, New York, 1965.

18. L. Kraft, Calcium Aluminate Based Cement as Dental Restorative Materials, in Ph.D. Thesis, Uppsala University, Sweden, 2002

19. J. Loof, Calcium Aluminate as Biomaterial, Design and Evaluation, in Ph.D. Thesis, Uppsala University, Sweden, 2008.

20. L. Kraft, M. Saksi, L. Hermansson, C. H. Pameijer, "A Five Year Retrospective Clinical Study of a Calcium- Aluminate in Retrograde Endodontics," J. Dent. Res., 881383 (2009).

21. H. Engqvist, J. E. Schultz-Walz, J. Lööf, G. A. Botton, D. Mayer, M. W. Phaneuf, N.-O. Ahnfelt, and L. Hermansson, "Chemical and Biological Integration of a Mouldable Bioactive Ceramic Material Capable of Forming Apatite in vivo in Teeth," Biomaterials, 25 2781-87 (2004).

22. H. Engqvist, G. A. Botton, M. Couillard, S. Mohammadi, J. Malmström, L. Emanuelsson, L. Hermansson, M. W. Phaneuf, and P. Thomsen, "A New Tool for High-Resolution Transmission Electron Microscopy of Intact Interfaces between Bone and Metallic Implants," J. Biomed. Mater. Res. A, 78 [1] 20-4 (2006).

23. H. Engqvist and L. Hermansson, "Chemically Bonded Bioceramics Based on Ca-Aluminates and Silicates," Ceram. Trans., 172 221-28 (2006).

24. L. Hermansson, J. Lööf, and T. Jarmar, "Integration Mechanisms towards Hard Tissue of Ca-Aluminate Based Materials," Key Eng. Mater., 396-398 183-86 (2009).

25. L. Hermansson, "Nanostructures and Specific Properties," pp. 105-29 in Nanostructural Bioceramics: Advances in Chemically Bonded Ceramics, Pan Stanford Publishing, 2015.

26. H. Engqvist, J.-E. Schultz-Walz, J. Loof, G. A. Botton, D. Mayer, M. W. Phaneuf, N.-O. Ahnfelt, and L. Hermansson "Chemical and Biological Integration of a Mouldable Bioactive Ceramic Material Capable of Forming Apatite in vivo in Teeth," Biomaterials, 25 [14] 2781-87 (2004).

27. H. Engqvist, G. A. Botton, M. Couillard, S. Mohammadi, J. Malmström, L. Emanuelsson, L. Hermansson, M. W. Phaneuf, and P. Thomsen, "A New Tool for High-Resolution Transmission Electron Microscopy of Intact Interfaces between Bone and Metallic Implants," J. Biomed. Mater. Res. A, 78 20-4 (2006).

28. L. Kraft, H. Engqvist, and L. Hermansson, "Early-Age Deformation, Drying Shrinkage and Thermal Dilatation 
in a New Type of Dental Restorative Material based on Calcium Aluminate Cement," Cem. Concr. Res., 34 [3] 439-46 (2004).

29. L. Hermansson, H. Engqvist, G. Gomez-Ortega, E. Abrahamsson, and K. Björklund, "Nanosize Biomaterials Based on Ca-Aluminate," Key Eng. Mater., 49 21-6 (2006).

30. N. Axén, H. Engqvist, J. Lööf, P. Thomsen, and L. Hermansson, "In vivo Hydrating Calcium Aluminate Coatings for Anchoring of Metal Implants in Bone," Key Eng. Mater., 284-286 831-34 (2005).

31. E. Unosson, E. Cai, E. Jiang, J. Loof, and H. Engqvist, "Antibacterial Properties of Dental Luting Agents Potential to Hinder the Development of Secondary Caries," Int. J. Dent., 2012529495 (2012).

32. L. Hermansson, "Nanostructures and Specific Properties," pp. 57-67 in Nanostructural Bioceramics: Advances in Chemically Bonded Ceramics, Pan Stanford Publishing, 2015.

33. J. Lööf, H. Engqvist, G. Gómez-Ortega, H. Spengler, N.-O. Ahnfelt, and L. Hermansson, "Mechanical Property Aspects of a Biomineral Based Dental Restorative System," Key Eng. Mater., 284-286 741-44 (2005).

34. L. Hermansson, L. Kraft, K. Lindqvist, N.-O. Ahnfelt, and H. Engqvist, "Flexural Strength Measurement of Ceramic Dental Restorative Materials," Key Eng. Mater., 361-363 873-76 (2008).

35. L. Hermansson, "Dental Applications within Chemically Bonded Bioceramics," pp. 71-9 in Nanostructural Bioceramics: Advances in Chemically Bonded Ceramics, Pan
Stanford Publishing, 2015.

36. C. H. Pameijer, O. Zmener, S. A. Serrano, and F. GarciaGodoy, "Sealing Properties of a Calcium Aluminate Luting Agent," Am. J. Dent., 23 [2] 121-24 (2010).

37. J. Åberg, Premixed Acidic Calcium Phosphate Cements, in Ph.D. Thesis, Uppsala University, Sweden, 2011.

38. J. Åberg, Ph D Thesis, Uppsala University, Premixed Acidic Calcium Phosphate Cements (2011).

39. H. Engqvist, M. Couillard, G. A. Botton, M. W. Phaneuf, N. Axén, N.-O. Ahnfelt, and L. Hermansson, "In vivo Bioactivity of a Novel Mineral Based Orthopaedic Biocement," Trends Biomater. Artif. Organs, 19 [1] 27-32 (2005).

40. L. Hermansson, H. Engqvisy, J. Lööf, G. Gomez-Ortega, E. Abrahamsson, and K. Björklund, "Nanosize biomaterials based on Ca-aluminates," Adv. Sci. Technol., 49 21-6 (2006).

41. A. Krajewski, A. Ravaglioli, E. Roncari, P. Pinasco, and L. Montanari, "Porous Ceramic Bodies for Drug Delivery," J. Mater. Sci.: Mater. Med., 11 [12] 763-67 (2000).

42. A. Lasserre and P. K. Bajpaj, "Ceramic drug-delivery devices," Crit. Rev. Ther. Drug Carrier Syst., 15 [1] 1-56 (1998).

43. L. Yang, B. Sheldon, and T. J. Webster, "Nanophase Ceramics for Improved Drug Delivery," Am. Ceram. Soc. Bull., 89 [2] 24-32 (2010).

44. J. Forsgren, Functional Ceramics in Biomedical Applications, in Ph.D. Thesis, Uppsala University, Sweden, 2010. 